\title{
Biomonitoring Road Dust Pollution Along Streets with Various Traffic Densities
}

\author{
Lenka Demková ${ }^{*}$, Jozef Oboňa ${ }^{1}$, Július Árvay², Jana Michalkováa, Tomáš Lošák ${ }^{4}$ \\ ${ }^{1}$ Department of Ecology, Faculty of Humanities and Natural Sciences, University of Prešov, Prešov, Slovakia \\ ${ }^{2}$ Department of Chemistry, Faculty of Biotechnology and Food Sciences, \\ Slovak University of Agriculture in Nitra, Nitra, Slovakia \\ ${ }^{3}$ Department of Geography and Applied Geoinformatics, University of Prešov, Prešov, Slovakia \\ ${ }^{4}$ Faculty of Regional Development and International Studies, Mendel University in Brno, Brno, Czech Republic
}

Received: 5 June 2018

Accepted: 7 October 2018

\begin{abstract}
Three lichen species (Phaeophyscia orbicularis, Physcia adscendens, and Xanthoria parietina), were sampled from the deciduous trees along nine streets of various traffic densities in Prešov, Slovakia. The total concentrations of risk elements (Al, As, Ba, Cd, Cr, Cu, Fe, $\mathrm{Li}, \mathrm{Mn}, \mathrm{Ni}, \mathrm{Pb}, \mathrm{Zn}$ ) were determined by the ICP-OES method. Phaeophyscia orbicularis showed the best ability to accumulate all evaluated risk elements except $\mathrm{Pb}$ and $\mathrm{Cr}$. X. parientina was found to be the least suitable for bioaccumulation purposes. The concentration of evaluated risk elements in lichen insoles came predominantly from traffic, which was confirmed by a significant positive correlation between risk elements and traffic density. Based on the results of contamination factor, evaluated streets were most polluted by $\mathrm{Cr}, \mathrm{Fe}, \mathrm{Ni}, \mathrm{Pb}$ and $\mathrm{Zn}$ and only slightly polluted by $\mathrm{Cd}$. Provably higher values of $\mathrm{Cd}, \mathrm{Cu}, \mathrm{Fe}, \mathrm{Ni}$ and $\mathrm{Zn}$ were measured in streets with higher traffic density. According to the cluster analysis, two groups of risk elements, expressing their origin, were found.
\end{abstract}

Keywords: lichens, air pollution, traffic density, fuel combustion, risk element

\section{Introduction}

The rapid development of modern society and continuous demand of land for infrastructural development in urban areas has caused great contamination pressure on the local environment [1]. Despite extensive environmental steps, the number of vehicles are growing at an unprecedented rate. The increasing volume of emissions originates from fuel

*e-mail: lenka.demkova@unipo.sk combustion $(\mathrm{Pb}$ and $\mathrm{Ba})$, tyre, brake, engine and vehicle component deterioration $(\mathrm{Cd}, \mathrm{Cr}, \mathrm{Cu}, \mathrm{Fe}, \mathrm{Mn}, \mathrm{Ni}$, $\mathrm{Sb}, \mathrm{V}$, and $\mathrm{Zn}$ ) and, indirectly, by resuspension of soil (Al, Fe, and associated elements) and street dust [2-3]. Among various heavy metals emission sources, vehicle emissions are known to be one of the main contributors in urban areas [4-6]. It has been shown repeatedly that road dust emissions containing heavy metals cause health problems such as black lung disease, silicosis, allergies, anaemia, cancers, asthma, etc. [7-8]. plant damage (photosynthesis disruption, cell membrane permeability problems, damages to root structures, reduction of chlorophyll content etc.) [9-10], and animal 
body damage (neurological damage, skeletal calcification and asphyxiation, reproduction decreasing etc.) [11], and reflects significantly on human health [12-14].

Prešov, the third largest city in Slovakia with a population of more than 93,000, has in recent years experienced a significant increase in traffic. Because a bypass to the city is missing, traffic passes through the centre of the city. Increasing traffic problems lead to decreasing air quality. Road dust and an accumulation of solid particles in the form of organic and inorganic pollutants affect human life quality and the quality of the environment [15-16].

Use of vegetation as a bioindicator of atmospheric risk element accumulation has received more attention worldwide due to the fact that this method has been found to be effective, cheap and simple to use [17-18]. Among the different organisms, lichens are considered one of the best bioindicators of environmental pollution because of their ability to accumulate airborne substance to concentrations far greater than those in the atmosphere, and the element contents of lichen thalli have proven to be directly correlated with environmental levels [19-20]. Additionally, lichens occur on various substrates, including rocks, which is mainly due to their resistance to desiccation in extreme temperature and efficiency in accumulating nutrients [21].

These features of lichens, combined with their extraordinary capability to grow in a large geographical area, rank them as an ideal reliable bioindicator of air pollution. Lichens were used by many authors in order to determine road dust emissions [22-24]. In the areas where lichen are absent, alternative methods based on transplants (lichens collected elsewhere, exposed in small nylon bags in selected stations), known as the "lichen bag technique" described by Godman and Roberts [25], should be used.

The main objectives of the study were: 1) to determine the levels of risk elements in lichens collected along streets with various traffic density, 2) to assess differences in risk element accumulation abilities between lichen species, and 3) to determine the influence of traffic density to the risk element concentration in lichen samples.

\section{Material and Methods}

\section{Study Area}

The study was performed in Prešov [49 $00^{\circ} 00.00^{\prime} \mathrm{N}$; $21^{\circ} 14$ '19.72'E] in the eastern part of Slovakia (Fig. 1). The city itself covers $70.4 \mathrm{~km}^{2}$ and the average altitude is $255 \mathrm{~m}$ a.s.l. Climate features are typical for a moderately warm-moderately wet and moderately cold-moderately wet climate region, with an average January temperature of -2 to $-6^{\circ} \mathrm{C}[26]$.

For research purposes, nine different streets of various traffic densities were selected (Fig. 1). The streets were, according to the traffic density, included in traffic density categories. The cars were counted during the expected rush hour, 6:30-8:30 a.m., and again 3:00-5:00 p.m. during a one-week (7 days) period. The average number of cars per hour was calculated. Based on the results, streets were included in three traffic groups: high traffic density (HD): $>600$ cars per hour, medium traffic density (MD): 599-200 cars per hour and low traffic density (LD): $<199$ cars per hour. Detailed information about the sampled streets is listed in Table 1.

\section{Lichen Sampling}

Three lichen species (Phaeophyscia orbicularis (Necker) Moberg, Physcia adscendens (Th. Fr.) H. Olivier, Xanthoria parietina (L.) Th. Fr.) commonly occurring in the middle-European geographical location were sampled along the nine streets in Prešov. The lichen samples were taken from deciduous trees (Aesculus sp., Cerasus sp., Tillia sp., Fraxinus sp., Populus sp.) that were approximately the same height, same circuit and approximately of the same bark characteristics (roughness). Lichen samples were taken up to $2 \mathrm{~m}$ high from the side facing the road. Control samples (two samples of each lichen species: Phaeophyscia orbicularis, Physcia adscendens, Xanthoria parietina) were taken in the neighbouring villages, approximately $3 \mathrm{~km}$ from Prešov city border,

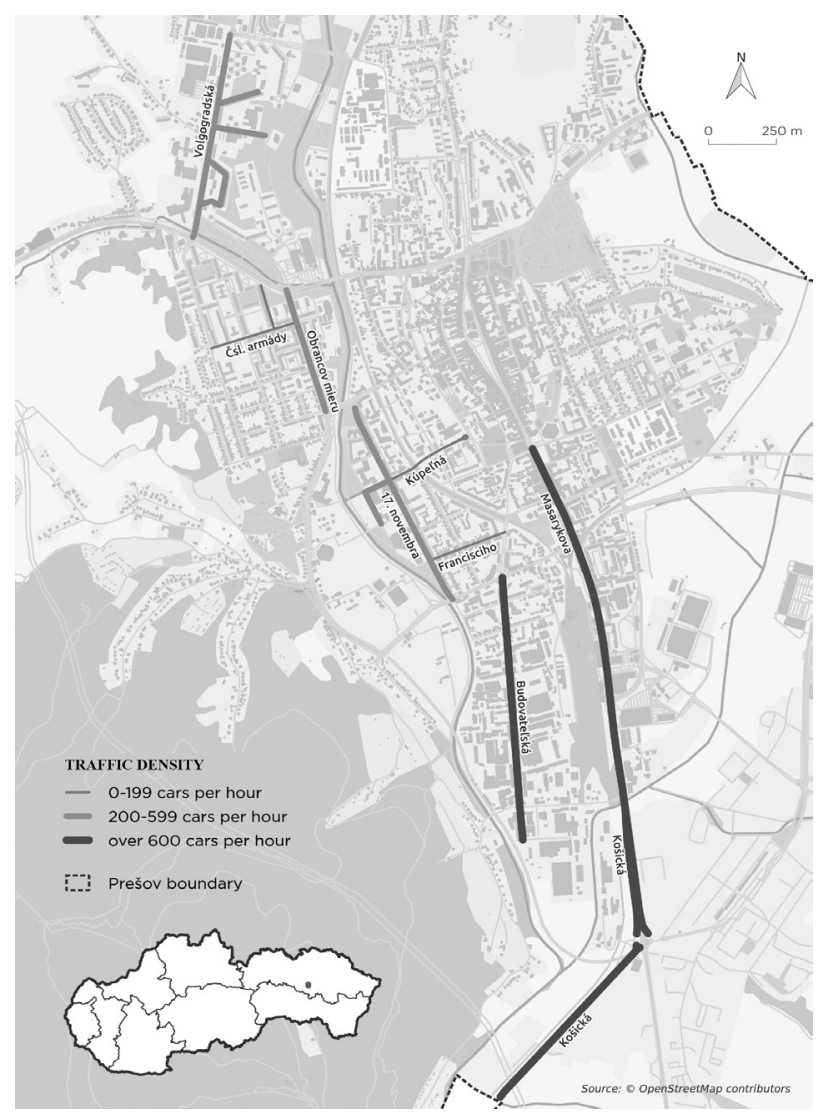

Fig. 1. The localization and traffic density categories of streets selected for monitoring in Prešov, Slovakia. 
Table 1. Characteristics of the selected streets.

\begin{tabular}{|c|c|c|c|c|}
\hline & \multirow{2}{*}{ Name of the street } & \multirow{2}{*}{ Traffic density } & \multicolumn{2}{|c|}{ GPS coordinates } \\
\hline & & & Latitude & Longitude \\
\hline 1 & Obrancov mieru (OMS) & MD & $48^{\circ} 59^{\prime} 53.765^{\prime \prime}$ & $21^{\circ} .14^{\prime} 54.985^{\prime \prime}$ \\
\hline 2 & Masarykova (MS) & HD & $48^{\circ} 59^{\prime} 13.326^{\prime \prime}$ & $21^{\circ} 14^{\prime} 54.985^{\prime \prime}$ \\
\hline 3 & Košická (KES) & HD & $48^{\circ} 58^{\prime} 13.061^{\prime \prime}$ & $21^{\circ} 15^{\prime} 07.112^{\prime \prime}$ \\
\hline 4 & 17. Novembra (NS) & MD & $48^{\circ} 59^{\prime} 29.749^{\prime \prime}$ & $21^{\circ} 14^{\prime} 03.552^{\prime \prime}$ \\
\hline 5 & Volgogradská (VS) & MD & $48^{\circ} 59^{\prime} 29.749^{\prime \prime}$ & $21^{\circ} 14^{\prime} 03.552^{\prime \prime}$ \\
\hline 6 & Budovatel'ská (BS) & HD & $48^{\circ} 53^{\prime} 30.026^{\prime \prime}$ & $21^{\circ} 14^{\prime} 37.096^{\prime \prime}$ \\
\hline 7 & Francisciho (FS) & LD & $48^{\circ} 59^{\prime} 16.688^{\prime \prime}$ & $21^{\circ} 14^{\prime} 20.237^{\prime \prime}$ \\
\hline 8 & Kúpel’ná (KS) & LD & $48^{\circ} 59^{\prime} 16.328^{\prime \prime}$ & $21^{\circ} 14^{\prime} 20.234^{\prime \prime}$ \\
\hline 9 & Československej armády (CAS) & LD & $48^{\circ} 59^{\prime} 49.844^{\prime \prime}$ & $21^{\circ} 13^{\prime} 23.818^{\prime \prime}$ \\
\hline
\end{tabular}

HD- high traffic density, MD-medium traffic density, LD-low traffic density

on trees at a distance of at least $0.5 \mathrm{~km}$ from the main road. Totals of 47 lichen samples and 6 controls were collected and stored in plastic bags at $-20^{\circ} \mathrm{C}$ prior to analysis.

Lichen samples were sampled in two replicates, during June and September 2017. Average daily temperature was $18.5^{\circ} \mathrm{C}$ in June and $17^{\circ} \mathrm{C}$ in September. Sampling was continued during dry days (without rain), with an average June and September humidity of $65 \%$ and $61 \%$. The wind force in both cases was under $4 \mathrm{~m} / \mathrm{s}$.

\section{Sample Preparation and Elemental Analysis}

Lichen samples were air-dried at $40^{\circ} \mathrm{C}$ in a hot oven Venticell 111 (BMT, a.s., Czech Republic) and homogenized using ceramic mortar. The dried and homogenized samples were digested with $5 \mathrm{~mL}$ of $69 \%$ $\mathrm{HNO}_{3}, 1 \mathrm{~mL}$ of $30 \% \mathrm{H}_{2} \mathrm{O}_{2}$ (TraceSELECT, HoneywellFluka, Bratislava) and $5 \mathrm{~mL}$ double deionized water $\left(\mathrm{ddH}_{2} \mathrm{O}\right)$ from Simplicity 185 (Millipore SAS, Molsheim, France) in PTFE (polytetrafluoroethylene) vessels under pressure in an Ethos One microwave system (Milestone Srl., Italy). The mineralized solutions were subsequently filtered through a quantitative filter paper Filtrak No. 390 (Munktell and Filtrak $\mathrm{GmbH}$ ) and filled to a volume of $50 \mathrm{~mL}$ with $\mathrm{ddH}_{2} \mathrm{O}$. A blank was carried out in the same way. The concentration of risk elements was determined using an ICP-OES Agilent 720 (Agilent Technologies, Germany). The operating conditions for ICP-OES spectrometer were: RF power: $1200 \mathrm{~W}$; plasma Ar flow rate: $15 \mathrm{~L} \mathrm{~min}^{-1}$; nebulizer Ar flow rate: $0.75 \mathrm{~L} \mathrm{~min}^{-1}$ and auxiliary Ar flow rate: $1.5 \mathrm{~L} \mathrm{~min}^{-1}$. For calibration

Table 2. Risk element concentrations in lichen samples sampled along the streets in Prešov city (Slovakia) and the values of contamination factor $\left(\mathrm{C}_{\mathrm{f}}\right)$ determined for sampling sites.

\begin{tabular}{|c|c|c|c|c|c|c|c|c|c|c|c|}
\hline & \multicolumn{11}{|c|}{ Risk elements $\left[\mathrm{mg} \mathrm{kg}^{-1} \mathrm{DW}\right]$} \\
\hline & $\mathrm{Al}$ & As & $\mathrm{Ba}$ & $\mathrm{Cd}$ & $\mathrm{Cr}$ & $\mathrm{Cu}$ & $\mathrm{Fe}$ & $\mathrm{Li}$ & $\mathrm{Mn}$ & $\mathrm{Ni}$ & $\mathrm{Pb}$ \\
\hline Min & 1060 & 0.90 & ND & 0.15 & 3.39 & 11.7 & 1721 & 1.26 & 36.8 & 1.55 & 12.0 \\
\hline Max & 2426 & 10.6 & 198 & 1.46 & 682 & 173 & 12125 & 8.04 & 765 & 11.6 & 3908 \\
\hline Median & 1796 & 3.25 & 67.5 & 0.79 & 10.2 & 58.3 & 5591 & 3.39 & 159 & 5.36 & 44.3 \\
\hline Average & 1778 & 4.04 & 76.8 & 0.77 & 26.0 & 69.5 & 5938 & 3.85 & 182 & 5.99 & 135 \\
\hline St. dev & 321 & 2.58 & 49.8 & 0.35 & 131 & 46.8 & 2830 & 1.78 & 141 & 2.81 & 756 \\
\hline \multicolumn{12}{|c|}{ Contamination factor $\left(\mathrm{C}_{\mathrm{f}}\right)$} \\
\hline Min & 1.78 & 1.36 & ND & 0.15 & 1.99 & 0.24 & 4.38 & 1.85 & 0.62 & 2.47 & 0.64 \\
\hline Max & 4.07 & 16.0 & 16.9 & 1.41 & 401 & 3.56 & 30.9 & 11.8 & 13.0 & 18.3 & 210 \\
\hline Median & 3.01 & 4.91 & 5.77 & 0.77 & 5.98 & 1.19 & 14.2 & 4.99 & 2.72 & 8.50 & 2.38 \\
\hline Average & 2.99 & 6.12 & 6.56 & 0.74 & 15.3 & 1.42 & 15.1 & 5.65 & 3.09 & 9.50 & 7.29 \\
\hline St. dev & 0.51 & 3.74 & 4.05 & 0.32 & 27.6 & 0.93 & 6.96 & 2.51 & 1.99 & 4.32 & 30.3 \\
\hline
\end{tabular}


curve, a mixed standard solution with content of $10 \mathrm{mg} \mathrm{L}^{-1}$ was used (100 $\mathrm{mg} \mathrm{L}^{-1}$ for Fe) (ICP 5 standard, Sigma-Aldrich, Germany).

\section{Contamination Factor and the Degree of Contamination}

In order to detect levels of polution in the evaluated streets, monitored through lichens, contamination factor and the degree of contamination were determined. Contamination factor provides a useful way of monitoring the time-course contamination process or its pattern in time [27].

The degree of contamination $\left(\mathrm{C}_{\mathrm{d}}\right)$ is given by means of contamination factors $\left(\mathrm{C}_{\mathrm{f}}\right) . \mathrm{C}_{\mathrm{f}}$ is the ratio of the current concentration of an element to the backgrounf level of that element in the evaluated media (soil, sediment or plant):

$$
\mathrm{C}_{\mathrm{f}}=\mathrm{Cl} / \mathrm{Bl}
$$

...where $\mathrm{Bl}$ is the background level of trace risk elements ( $\mathrm{mg} \mathrm{kg}^{-1} \mathrm{DW}$ ) obtained from the control area or the lowest concentration value detected for each element [28-29]. In our case the average values of risk elements determined in control samples were used as background values. The background levels of $\mathrm{Al}, \mathrm{As}, \mathrm{Ba}, \mathrm{Cd}, \mathrm{Cr}, \mathrm{Cu}, \mathrm{Fe}, \mathrm{Li}, \mathrm{Mn}, \mathrm{Ni}, \mathrm{Pb}$ and $\mathrm{Zn}$ are $595 ; 0.66 ; 11.7 ; 1.03 ; 1.7 ; 48.7 ; 393 ; 0.68$; $58.9 ; 0.63 ; 18.6 ; 4.52 \mathrm{mg} \mathrm{kg}^{-1}$ DW. Degree of contamination is considered as negligible when $\mathrm{C}_{\mathrm{d}} \geq 1$; moderate when $1<\mathrm{C}_{\mathrm{d}} \leq 3$; severe when $<3 \mathrm{C}_{\mathrm{d}} \leq 6$; and very severe when $\mathrm{C}_{d}>6$. Contamination factors were calcuated for each metal at each lichen sample. Subsequently, the degree of contamination was calculated for each sampling site as the mean of contamination factors of individual trace elements. Degree of contamination was calculated in general for each evaluated street in Prešov.

\section{Map Processing, Data Processing and Statistical Evaluation}

The map outputs were processed using the open source Geographic Information System (GIS) using software QGIS (version 2.18) and open data from OpenStreetMap contributors [30]. In order to determine the differences in risk element concentrations between lichen species, streets and various traffic density categories, one-way ANOVA test for normally distributed and Kruskal-Wallis test for non-normally distrubuted data were used. Analysis was completed by Tukey's post-hoc test in order to detect species with signifficantly different risk elements accumulation ability. Spearman's correlation analysis was used to determine the correlation relationship between risk elements themeselves, and between risk elements and road traffic density. One-way Anova test/Kruskall-Wallis test was the same as Spearman's correlation coefficent, which were considered statistically significant if $P$ value was less than 0.05 and 0.01. Cluster analysis (CA) was performed using Euclidean distances in order to group risk elements based on their contamination factor. PCA (principal component analysis) was used in order to distinguish between streets based on occurrence the risk elements. All statistical analyses were performed using $\mathrm{R}$ studio (R Studio Team, Boston). Statistical analyses were carried out after the data were log transformed (normalized).

\section{Results and Discussion}

The descriptive statistic for the values of risk elements determined in lichen samples sampled along the streets of Prešov and the values of contamination factor expressing the level of pollution, especially for each evaluated risk element, are listed in Table 2. The concentration of risk elements in lichen samples ranged from 1060-2426 mg kg-1 for $\mathrm{Al}$; $\mathrm{ND}$ (not detected) -198 $\mathrm{mg} \mathrm{kg}^{-1}$ for $\mathrm{Ba}$; $0.15-1.46 \mathrm{mg} \cdot \mathrm{kg}^{-1}$ for $\mathrm{Cd}$; 3.39-682 $\mathrm{mg} \mathrm{kg}^{-1}$ for $\mathrm{Cr}$; $11.7-173 \mathrm{mg} \mathrm{kg}^{-1}$ for $\mathrm{Cu}$; $1721-12125 \mathrm{mg} \mathrm{kg}^{-1}$ for $\mathrm{Fe}$; $1.26-8.04 \mathrm{mg} \mathrm{kg}^{-1}$ for $\mathrm{Li}$; 36.8-765 mg kg-1 for Mn; 1.55-11.6 mg kg $\mathrm{mg}^{-1}$; 12.1-3908 mg kg-1 for $\mathrm{Pb}$; 49.3-467 $\mathrm{mg} \mathrm{kg}^{-1}$ for $\mathrm{Zn}$; 0.90-10.6 mg kg-1 for As; and ND-1.16 mg kg-1 for Se.

The values of $\mathrm{Cu}$ were considered as extremely high comparing studies of authors Zigmond and Urák [31] and Klimek et al. [32], where the values of $\mathrm{Cu}$ ranged between $0.42-6.51 \mathrm{mg} \mathrm{kg}^{-1}$ and $5.7-9.0 \mathrm{mg} \mathrm{kg}^{-1}$, respectively. The values of $\mathrm{Ni}$ in the study of Klimek at al. (2015) also reached lower values (0.9-1.5 mg kg-1). According to Markert [33, 34] and Aksoy and Öztürk [35], normal levels of $\mathrm{Pb}, \mathrm{Zn}, \mathrm{Cu}$, $\mathrm{Mn}$ and $\mathrm{Fe}$ in uncontaminated areas are 2-10 $\mathrm{mg} \mathrm{kg}^{-1}$, 20-300 mg kg-1, 5-20 mg kg-1, 20-100 mg kg-1 and $50-250 \mathrm{mg} \mathrm{kg}^{-1}$, respectively. The values of $\mathrm{Mn}$ and $\mathrm{Fe}$ were exceeded in all cases and the values of $\mathrm{Pb}, \mathrm{Cu}$ and $\mathrm{Zn}$ were exceeded in most of the samples. In the study investigated in Isfahan metropolis, central Iran, mean concentrations of $\mathrm{As}, \mathrm{Cd}, \mathrm{Cu}, \mathrm{Ni}, \mathrm{Pb}$ and $\mathrm{Zn}$ were 22.2, 2.14, 182, 66.6, 393 and $707 \mathrm{mg} \mathrm{kg}^{-1}$ [1]. Average values of listed risk elements were much lower in our case. Nine streets in Prešov, which were selected for sampling, were divided into three categories according to traffic density. In the lichen samples collected along the streets with the highest traffic density, the values of $\mathrm{Al}, \mathrm{Ag}, \mathrm{Ba}, \mathrm{Cd}, \mathrm{Cr}, \mathrm{Cu}, \mathrm{Fe}, \mathrm{Li}, \mathrm{Mn}, \mathrm{Ni}, \mathrm{Pb}$, $\mathrm{Sr}, \mathrm{Zn}, \mathrm{As}$ and Se were approximately 17, 60, 53, 40, $84,72,46,40,23,42,88,23,63,99$, and $88 \%$ lower, respectively, compared with the results reached from the lichens sampled on the streets with the lowest traffic densities (Fig. 2). Differences between average values of risk elements sampled in the streets with low traffic density and medium traffic density were not significant. Actually, in the case of $\mathrm{Cd}, \mathrm{Mn}, \mathrm{Sr}$ and $\mathrm{As}$, the values were higher in the streets with low traffic density.

The correlation relationship between evaluated risk elements except $\mathrm{Cr}, \mathrm{Pb}$ and $\mathrm{Mn}$, gave significant positive 
Table 3. Correlation relationships between risk element values themselves and between risk element values and traffic density (TD).

\begin{tabular}{|c|c|c|c|c|c|c|c|c|c|c|c|c|}
\hline & $\mathrm{Al}$ & $\mathrm{Ba}$ & $\mathrm{Cd}$ & $\mathrm{Cr}$ & $\mathrm{Cu}$ & $\mathrm{Fe}$ & $\mathrm{Li}$ & $\mathrm{Mn}$ & $\mathrm{Ni}$ & $\mathrm{Pb}$ & $\mathrm{Zn}$ & $\mathrm{As}$ \\
\hline $\mathrm{TD}$ & $0.43^{* *}$ & $0.52^{* *}$ & $0.51^{* *}$ & $0.50^{* *}$ & $0.71^{* *}$ & $0.57^{* *}$ & $0.45^{* *}$ & 0.09 & $0.58^{*}$ & $0.44^{* *}$ & $0.67^{* *}$ & $0.28^{*}$ \\
\hline $\mathrm{Al}$ & & $0.65^{* *}$ & $0.51^{* *}$ & 0.03 & $0.66^{* *}$ & $0.84^{* *}$ & $0.85^{* *}$ & $0.63^{* *}$ & $0.82^{* *}$ & 0.02 & $0.59^{* *}$ & $0.59^{* *}$ \\
\hline $\mathrm{Ba}$ & & & $0.76^{* *}$ & -0.19 & $0.79^{* *}$ & $0.82^{* *}$ & $0.69^{* *}$ & $0.54^{* *}$ & $0.86^{* *}$ & -0.19 & $0.69^{* *}$ & $0.67^{* *}$ \\
\hline $\mathrm{Cd}$ & & & & 0.18 & $0.74^{* *}$ & $0.77^{* *}$ & $0.62^{* *}$ & $0.47^{* *}$ & $0.81^{* *}$ & 0.18 & $0.78^{* *}$ & $0.66^{* *}$ \\
\hline $\mathrm{Cr}$ & & & & & 0.16 & 0.14 & 0.03 & 0.06 & 0.09 & $0.99^{* *}$ & $0.43^{* *}$ & 0.28 \\
\hline $\mathrm{Cu}$ & & & & & & $0.81^{* *}$ & $0.68^{* *}$ & $0.56^{* *}$ & $0.86^{* *}$ & 0.16 & $0.88^{* *}$ & $0.67^{* *}$ \\
\hline $\mathrm{Fe}$ & & & & & & & $0.91^{* *}$ & $0.76^{* *}$ & $0.97^{* *}$ & 0.13 & $0.78^{* *}$ & $0.75^{* *}$ \\
\hline $\mathrm{Li}$ & & & & & & & & $0.78^{* *}$ & $0.91^{* *}$ & 0.02 & $0.56^{* *}$ & $0.63^{* *}$ \\
\hline $\mathrm{Mn}$ & & & & & & & & & $0.73^{* *}$ & 0.03 & $0.47^{* *}$ & $0.43^{* *}$ \\
\hline $\mathrm{Ni}$ & & & & & & & & & & 0.07 & $0.78^{* *}$ & $0.75^{* *}$ \\
\hline $\mathrm{Pb}$ & & & & & & & & & & & $0.42^{* *}$ & 0.28 \\
\hline $\mathrm{Zn}$ & & & & & & & & & & & & $0.74^{* *}$ \\
\hline
\end{tabular}

correlation with car density, which indicates that they are related to traffic (Table 3). The main emission source of $\mathrm{Pb}$ into the earth's atmosphere was the combustion of gasoline. Despite its phasing-out and the decreasing trend in the atmosphere, $\mathrm{Pb}$ remains a significant urban air pollutant [36]. According to UNECE (United Nations Economic Commission for Europe), As and Se exhaust emissions are released during fuel combustion while $\mathrm{Cd}, \mathrm{Cr}, \mathrm{Cu}, \mathrm{Ni}, \mathrm{Pb}$, and $\mathrm{Zn}$ exhaust emissions are released during lubricant oil combustion [37]. According to previous reports [38-40], $\mathrm{Zn}$ in dust can also originate from the wear and tear of vulcanized vehicle tyres and corrosion of galvanized automobile parts. Barium is used as $\mathrm{BaSO}_{4}$ to increase the density of brake pads. Sternbeck et al. [41] found that heavy-duty vehicles are strong emitters of Ba-containing fine particles. Lithium is contained in petrol, aluminium is used as a corrosion inhibitor and iron is observed in car construction [42].

Significant positive correlation between risk elements, suggest common sources of them [43]. Zinc gave significant positive correlation with all evaluated risk elements, probably because it is related to vehicle corrosion the same as oil combustion. All evaluated risk elements (except Mn) gave significant positive correlations between themselves. They are released into the environment as the result of violation of the vehicle body, because they are part of alloys, coatings, or sheets. Lead gave significant positive correlation only with $\mathrm{Cr}$.

The values of risk elements determined in different lichen species collected along Prešov streets are listed in Table 4. The highest average values of all evaluated risk elements except $\mathrm{Pb}$ and $\mathrm{Cr}$ were determined in the samples of $P$. orbicularis. The lowest risk element concentration was, in all cases, determined in the samples of X. parietina. P. Orbicularis, which was found to be a very effective bioindicator of traffic pollution [44], and showed good resilience and high accumulation ability [21]. Scerbo et al. [45] used X. parientina for air quality biomonitoring in Italy. Determined values of risk elements in X. parientina, were, in our case, at least two times higher.

\section{Contamination Factor and Degree of Contamination}

In general, Prešov streets are negligibly contaminated by $\mathrm{Cd}$, moderately contaminated by $\mathrm{Al}$ and $\mathrm{Cu}$, severely contaminated by $\mathrm{As}, \mathrm{Ba}, \mathrm{Li}, \mathrm{Mn}$ and $\mathrm{Pb}$ and very severely contaminated by $\mathrm{Cr}, \mathrm{Fe}, \mathrm{Ni}, \mathrm{Pb}$ and $\mathrm{Zn}$.

The level of pollution on Prešov streets was expressed by the degree of contamination $\left(\mathrm{C}_{\mathrm{d}}\right)$ (Figs 3-4) which was calculated for each sampling site, and subsequently the average value for each street was expressed. The values of $\mathrm{C}_{\mathrm{d}}$ decreased in the order $\mathrm{MS}>\mathrm{KES}>\mathrm{BS}>\mathrm{NS}>\mathrm{CSA}>\mathrm{OMS}>\mathrm{FS}>\mathrm{VS}>\mathrm{KS}$, which does not correspond with the observed traffic density. The values of risk element and finally the values of $\mathrm{C}_{\mathrm{d}}$ are, in our view, predominantly influenced by traffic density, but total pollution could be affected by other factors such as local air flow influenced by the surrounding built-up areas, the presence/absence of green areas, and the presence of local pollution sources (industrial factories, landfills), etc.

\section{One-Way ANOVA Test}

One-way ANOVA test confirmed significant differences in risk element concentrations between streets with various traffic densities. Significantly higher values of $\mathrm{Ba}, \mathrm{Cd}, \mathrm{Cu}, \mathrm{Fe}, \mathrm{Ni}, \mathrm{Sr}, \mathrm{Zn}$ and $\mathrm{As}$ in lichen insoles were determined at streets with the highest traffic densities (Table 5). The highest values of all evaluated risk elements (except $\mathrm{Ba}, \mathrm{Li}, \mathrm{Mn}, \mathrm{Pb}$ and Se) were determined in lichen samples collected along 

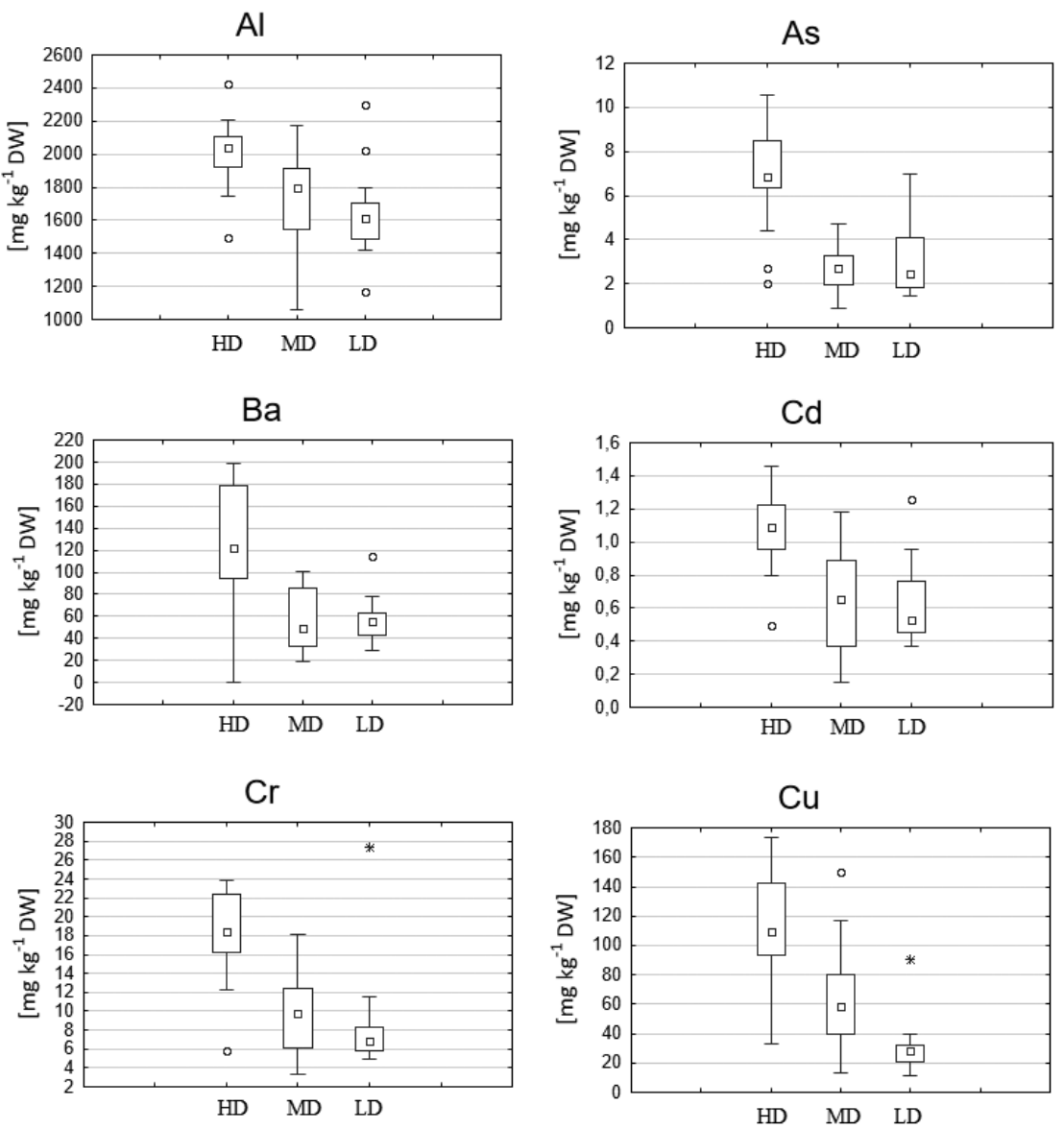

$\mathrm{Fe}$
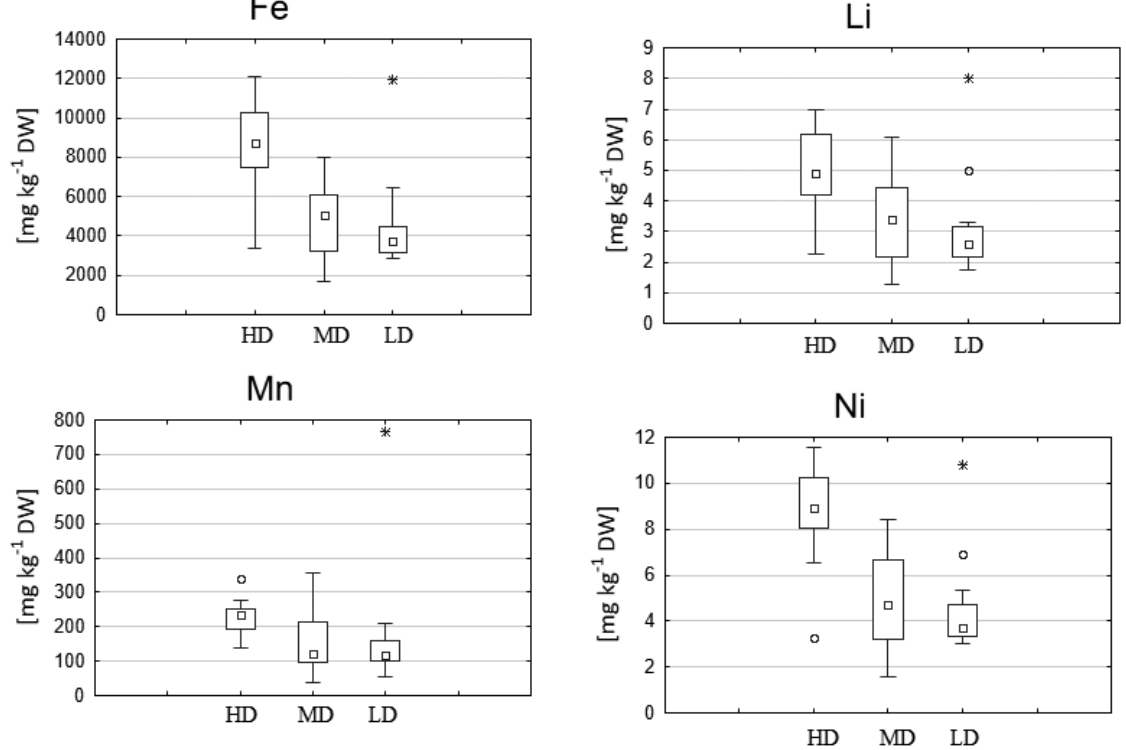

$\mathrm{Pb}$
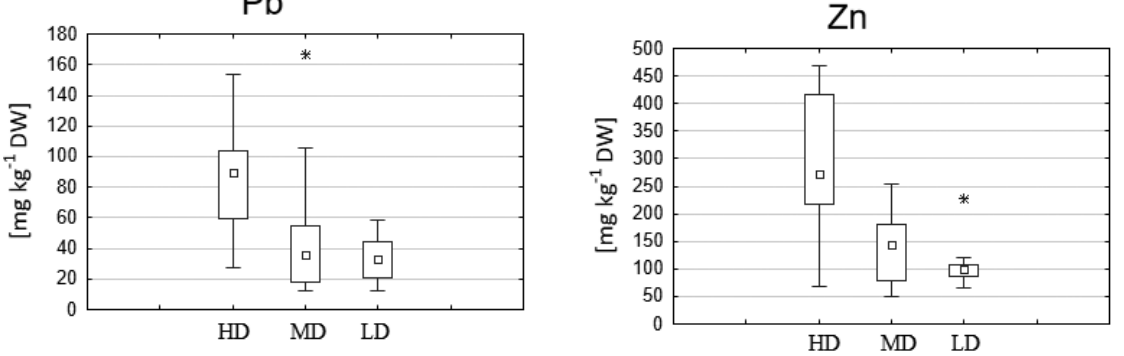

Fig. 2. Average values ( $\square$ median; |-- min-max; $\square \square 25 \%-75 \%{ }^{\circ}$ outlying value, ${ }^{*}$ extreme value) of risk elements in lichen samples according to traffic density (TD) categories (HD- high traffic density, MD-medium traffic density, LD-low traffic density). 
Table 4. Values (minimum-maximum (median \pm standard deviation)) of risk elements determined in different lichen species (regardless the street).

\begin{tabular}{|c|c|c|}
\hline \multirow{2}{*}{$\begin{array}{c}\text { Risk element } \\
{\left[\mathrm{mg} \mathrm{kg}^{-1}\right]}\end{array}$} & \multicolumn{2}{|c|}{ Lichen species } \\
\hline & P. orbicularis & P. adscendens \\
\hline $\mathrm{Al}$ & $\begin{array}{c}1490-2426 \\
(1924 \pm 217)\end{array}$ & $\begin{array}{c}1060-2295 \\
(1650 \pm 346)\end{array}$ \\
\hline $\mathrm{Ba}$ & $\begin{array}{c}40.2-198 \\
(94.9 \pm 46.7)\end{array}$ & $\begin{array}{c}0.0-135 \\
(45.4 \pm 35.1)\end{array}$ \\
\hline $\mathrm{Cd}$ & $\begin{array}{c}0.37-1.46 \\
(0.92 \pm 0.31)\end{array}$ & $\begin{array}{c}0.15-1.26 \\
(0.63 \pm 0.31)\end{array}$ \\
\hline $\mathrm{Cr}$ & $\begin{array}{c}5.75-23.8 \\
(15.2 \pm 5.55)\end{array}$ & $\begin{array}{c}3.39-682 \\
(8.22 \pm 146)\end{array}$ \\
\hline $\mathrm{Cu}$ & $\begin{array}{c}21.8-173 \\
(88.8 \pm 45.9)\end{array}$ & $\begin{array}{c}12.9-141 \\
(41.0 \pm 34.4)\end{array}$ \\
\hline $\mathrm{Fe}$ & $\begin{array}{l}3171-12125 \\
(7341 \pm 2463)\end{array}$ & $\begin{array}{c}1721-11933 \\
(4356 \pm 2555)\end{array}$ \\
\hline $\mathrm{Li}$ & $\begin{array}{c}1.95-6.96 \\
(4.85 \pm 1.48)\end{array}$ & $\begin{array}{c}1.26-8.04 \\
(2.67 \pm 1.53)\end{array}$ \\
\hline $\mathrm{Mn}$ & $\begin{array}{c}80.9-354 \\
(229 \pm 74.4)\end{array}$ & $\begin{array}{c}36.8-765 \\
(110 \pm 152)\end{array}$ \\
\hline $\mathrm{Ni}$ & $\begin{array}{c}3.0-11.5 \\
(7.88 \pm 2.47)\end{array}$ & $\begin{array}{c}1.55-10.8 \\
(4.40 \pm 2.38)\end{array}$ \\
\hline $\mathrm{Pb}$ & $\begin{array}{c}20.4-166 \\
(59.3 \pm 38.9)\end{array}$ & $\begin{array}{c}12.3-3908 \\
(36.4 \pm 844)\end{array}$ \\
\hline $\mathrm{Zn}$ & $\begin{array}{c}66.0-451 \\
(197 \pm 114)\end{array}$ & $\begin{array}{c}49.2-467 \\
(128 \pm 110)\end{array}$ \\
\hline As & $\begin{array}{c}1.85-10.6 \\
(4.03 \pm 2.52)\end{array}$ & $\begin{array}{c}0.9-9.47 \\
(2.86 \pm 2.24)\end{array}$ \\
\hline
\end{tabular}

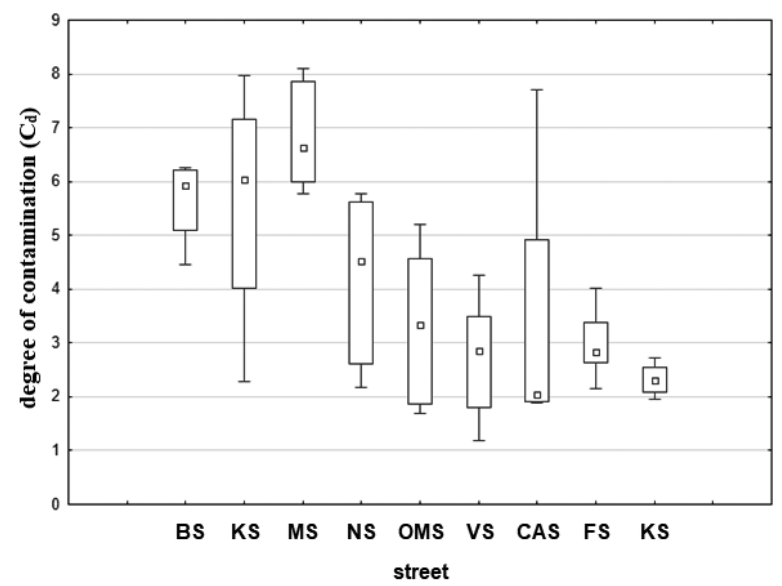

Fig. 3. Degree of contamination in nine streets in Prešov: BS - Budovatel'ská; KES - Košická; MS - Masaryková; NS - 17. Novembra; OMS - Obrancov mieru; VS - Volgogradská; CAS ČS armády; FS - Francisciho, and KS - Kúpel'ná, with various traffic densities based on the risk elements determined in lichen samples ( $\square$ median; |--| min-max; $\square \square 25 \%-75 \%$ ).

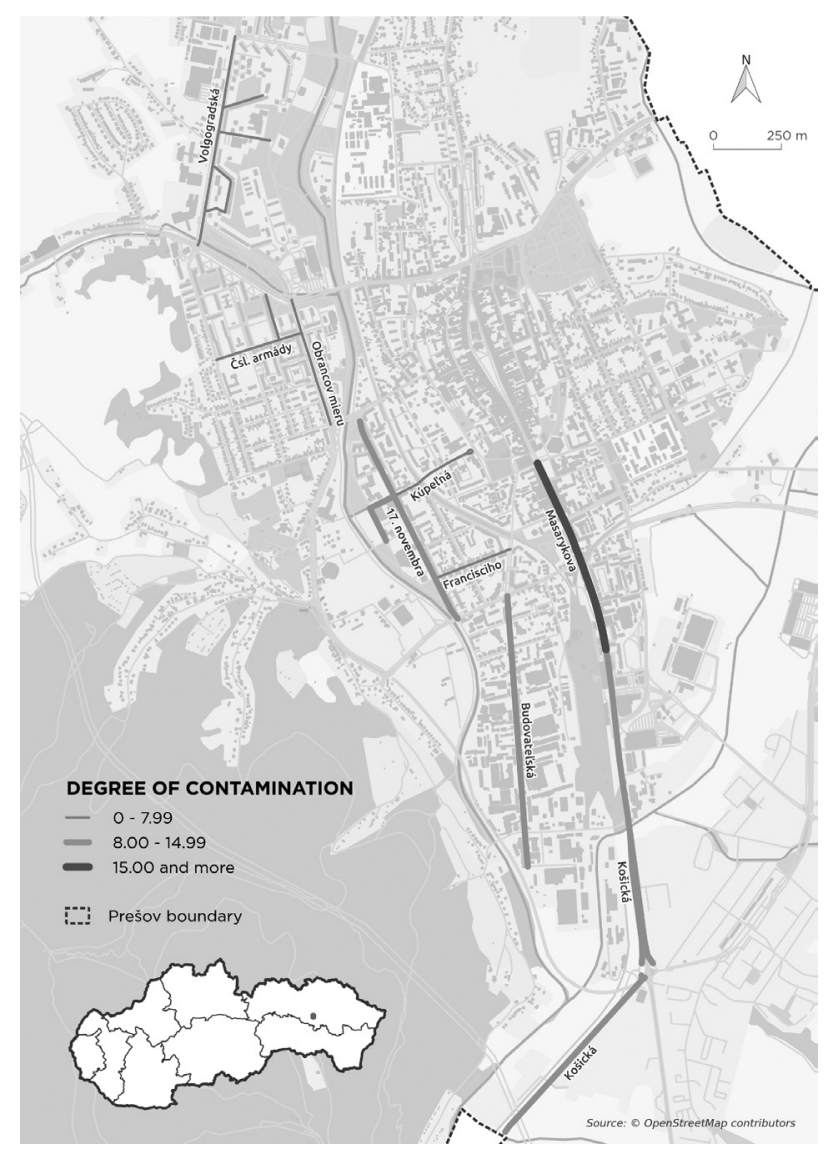

Fig. 4. Degree of contamination on evaluated streets in Prešov, Slovakia.

MS. The values of $\mathrm{Cr}, \mathrm{Cu}, \mathrm{Fe}$ and $\mathrm{Pb}$ were much higher compared with the other two streets, included the high traffic density group. Especially the average value of lead, which on the other streets ranged $23-72 \mathrm{mg} \mathrm{kg}^{-1}$, reached the MS average value of $740 \mathrm{mg} \mathrm{kg}^{-1}$.

The significantly highest ability to accumulate $\mathrm{Al}$, $\mathrm{Ag}, \mathrm{Ba}, \mathrm{Cd}, \mathrm{Cu}, \mathrm{Fe}, \mathrm{Li}, \mathrm{Ni}$ and $\mathrm{Sr}$ was found for $P$. orbicularis. Tukey post hoc test confirmed significant differences in the ability to accumulate As between $X$. parientina and P.orbicularis, and in the ability to accumulate $\mathrm{Se}$ between $P$. orbicularis and $P$. adscendens.

Significant differences were also found between individual streets. MS included in the HD group was found to be the most polluted. The values of $\mathrm{Cd}, \mathrm{Cu}$, $\mathrm{Fe}, \mathrm{Ni}$ and $\mathrm{Zn}$ were significantly highest at the samples sampled in this street.

\section{Cluster Analysis and PCA Analysis}

Cluster analysis (squared Euclidean distance) and Wards method were performed to identify groups of risk elements with similar origins. For analysis needs, the values of contamination factor were used. Results are shown in dendrogram (Fig. 5), where two groups of risk elements were identified. Group 1 includes $\mathrm{Zn}$, $\mathrm{Pb}$ and $\mathrm{Cr}$. The main source of these elements in rural 
Table 5. One-way ANOVA test for comparing the values of risk elements in lichen samples between streets with various traffic densities, between different lichen species and different streets.

\begin{tabular}{|c|c|c|c|c|c|c|c|c|c|c|c|c|}
\hline Element & Factor & $\mathrm{df}$ & $\mathrm{F}$ & $\mathrm{p}$ & Factor & $\mathrm{df}$ & $\mathrm{F}$ & $\mathrm{p}$ & Factor & $\mathrm{df}$ & $\mathrm{F}$ & $\mathrm{p}$ \\
\hline $\mathrm{Al}$ & \multirow{13}{*}{$\begin{array}{l}\text { Traffic } \\
\text { density }\end{array}$} & 2 & 2.44 & 0.09 & \multirow{13}{*}{$\begin{array}{l}\text { Lichen } \\
\text { species }\end{array}$} & 2 & 5.13 & $0.01 * *$ & \multirow{13}{*}{ Street } & 2 & 2.11 & 0.06 \\
\hline As & & 2 & 4.44 & $0.02 * *$ & & 2 & 3.75 & $0.03 *$ & & 2 & 8.21 & $2.2 \mathrm{e}^{-06 * *}$ \\
\hline $\mathrm{Ba}$ & & 2 & 5.88 & $0.005 * *$ & & 2 & 9.27 & $0.001 * *$ & & 2 & 3.59 & $0.003 * *$ \\
\hline $\mathrm{Cd}$ & & 2 & 6.92 & $0.002 * *$ & & 2 & 4.19 & $0.02 *$ & & 2 & 5.84 & $7.1 \mathrm{e}^{-05 * *}$ \\
\hline $\mathrm{Cr}$ & & 2 & 1.19 & 0.315 & & 2 & 0.480 & 0.62 & & 2 & 0.96 & 0.48 \\
\hline $\mathrm{Cu}$ & & 2 & 12.6 & $4.8 \mathrm{e}^{-05 * *}$ & & 2 & 7.73 & $0.001 * *$ & & 2 & 8.52 & $1.4 \mathrm{e}^{-06 * *}$ \\
\hline $\mathrm{Fe}$ & & 2 & 3.34 & $0.02 *$ & & 2 & 6.66 & $0.003 * *$ & & 2 & 4.20 & $0.001^{* *}$ \\
\hline $\mathrm{Li}$ & & 2 & 2.37 & 0.105 & & 2 & 8.93 & $0.001 * *$ & & 2 & 2.02 & 0.07 \\
\hline $\mathrm{Mn}$ & & 2 & 0.19 & 0.83 & & 2 & 1.98 & 0.15 & & 2 & 1.62 & 0.15 \\
\hline $\mathrm{Ni}$ & & 2 & 4.83 & $0.01 *$ & & 2 & 8.36 & $0.001 * *$ & & 2 & 4.39 & $0.001 * *$ \\
\hline $\mathrm{Pb}$ & & 2 & 1.29 & 0.28 & & 2 & 0.46 & 0.63 & & 2 & 0.99 & 0.47 \\
\hline $\mathrm{Sr}$ & & 2 & 6.37 & $0.003 * *$ & & 2 & 7.77 & $0.001 * *$ & & 2 & 2.43 & $0.031^{*}$ \\
\hline $\mathrm{Zn}$ & & 2 & 13.42 & $2.8 \mathrm{e}^{-05 * *}$ & & 2 & 2.1 & 0.13 & & 2 & 19.1 & $3.9 \mathrm{e}^{-11 * *}$ \\
\hline
\end{tabular}

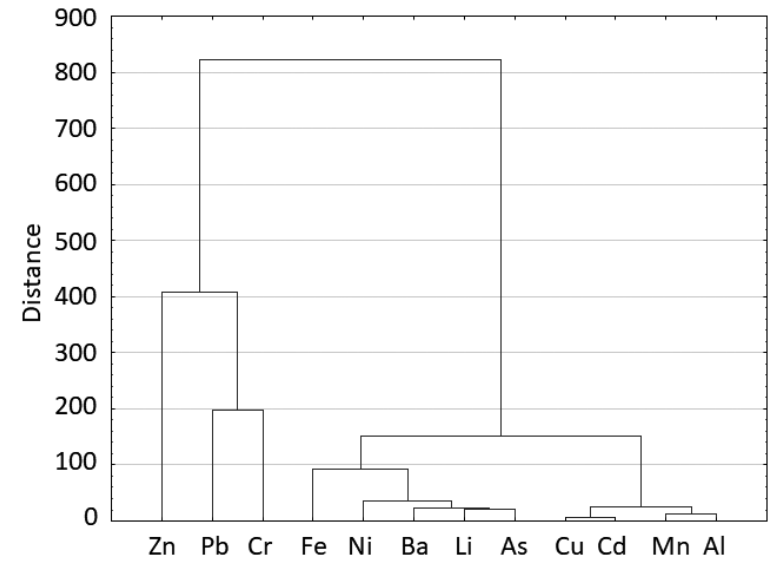

Fig. 5. Dendrogram observed by contamination factor values. environments is vehicle exhaust and combustion [21, 46], and chromium may also be released from traffic emissions due to tire, brake and engine wear [47]. Risk elements included in Group 1 correlated between themselves and correlate also with traffic density except for $\mathrm{Zn}$, which does not correlate with other risk elements.

Group 2 includes all other evaluated risk elements. Their origin could be affected not only by traffic, but to a large extent by various industrial activities. Inside group 2 we can identify two sub-groups. The elements $\mathrm{Fe}, \mathrm{Ni}, \mathrm{Ba}, \mathrm{Li}$ and $\mathrm{As}$ are released into the environment not only by vehicle exhaust but also through the combustion of coal or other fossil fuels. Additionally, nickel and iron are widely used in the steel industry and construction materials [48]. Barium is extensively used

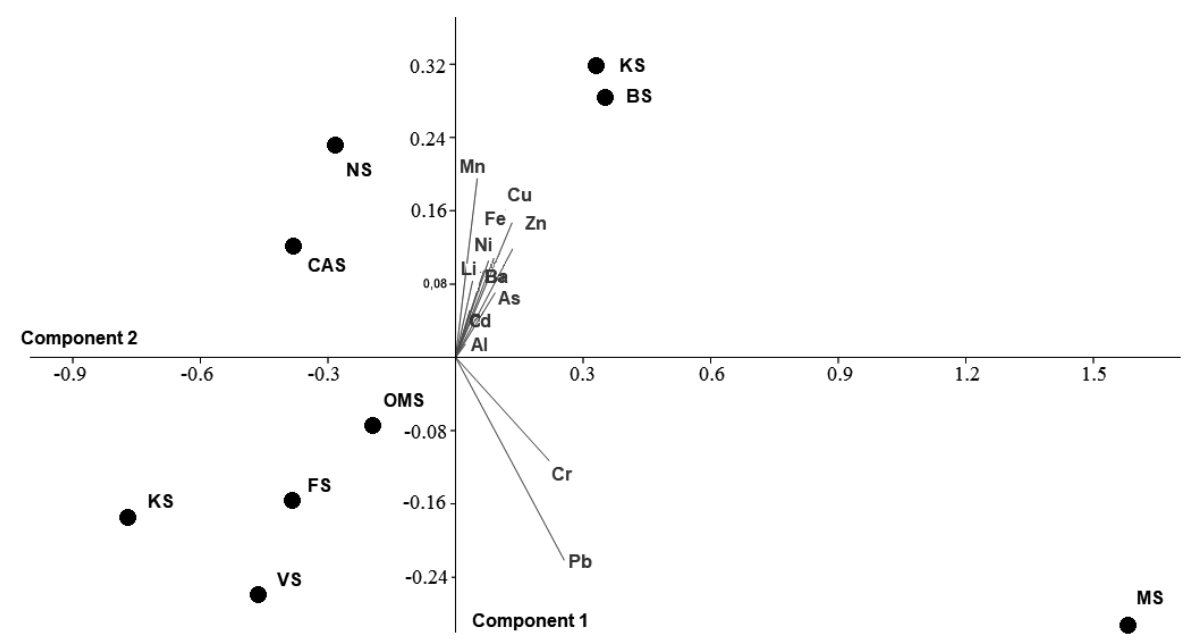

Fig. 6. PCA biplot showing separation of different risk elements based on various street densities. 
in the rubber industry and could be released from tires [42]. The elements $\mathrm{Cu}, \mathrm{Cd}, \mathrm{Mn}$ and $\mathrm{Al}$, which create the second sub-group, have very low contamination factor values. They are widely used in car-body materials, for example in alloys against corrosion and various industries [8].

Principal component analysis distinguished streets based on risk elements. The PCA displays the separation of different streets based on the determined parameters (Fig. 6). Principal component analysis resulted in a reduction of the initial dimension of dataset to two components, which explained $93.6 \%$ of the data variation (component 1: $83.5 \%$; component 2: 10.1\%). The streets classified as HF were determined to be the most influenced by risk element pollution. Risk elements such as $\mathrm{Al}, \mathrm{As}, \mathrm{Ba}, \mathrm{Cd}, \mathrm{Cu}, \mathrm{Li}, \mathrm{Mn}, \mathrm{Ni}$ and $\mathrm{Zn}$ showed similar direction and participated to the contamination of Košická and Budovatel'ská streets. The contamination by $\mathrm{Pb}$ and $\mathrm{Cr}$ was the most extensive at Masaryková Street.

\section{Conclusions}

The values of risk elements at the streets categorized as HD were several times higher comparing LD streets. The difference between the streets with low and medium density wasn't significant. Traffic as the main source of risk elements was confirmed by Spearman's coefficient, which shows significant correlation between most of evaluated risk elements with traffic density. Comparing lichen species used for research, P. orbicularis was found to be the most suitable and $X$. parientina the least suitable for risk element monitoring purposes. Based on the results of contamination factors, the streets of Prešov were most polluted by the elements $\mathrm{Cr}, \mathrm{Fe}, \mathrm{Ni}$, $\mathrm{Pb}$ and $\mathrm{Zn}$.

\section{Acknowledgements}

This work was supported by a project of the Ministry of Education, Science, Research and Sport of the Slovak Republic VEGA 1/0326/18 and by the Grand Agency of Prešov University, grant No. GaPU 27/2018.

\section{Conflict of Interest}

The authors declare no conflict of interest.

\section{References}

1. SOLTANI N., KESHAVARZI B., MOORE F., TAVAKOL T., LAHIJANZADEH A.R., JAAFARZADEH N., KERMANI M. Ecological and human health hazards of heavy metals and polycyclic aromatic hydrocarbons (PAHs) in road dust of Isfahan metropolis, Iran. Science of Total Environment, 505, 712, 2015.
2. LIU Q., SCHAUER J.J. Local-acting air pollutant emissions from road vehicles. In Environmental impacts of road vehicles: past, present, and future,1st ed.; Harrison, R.M., Hester, R.E. Eds., Royal Society of Chemistry: Great Britain, 46, 2017.

3. DOUGLAS B.S., HUDSON A.C., PARK J.H., HODGE V., PORTER H., SPAULDING W.G. Buellia dispersa (Lichens) used as bio-indicator for air pollution transport: A case study within the Las Vegas Valley, Nevada (USA). Environments, 4 (4), 94, 2017.

4. ZHANG M., LU X., CHEN H., GAO P., FU Y. Multielement characterization and source identification of trace metal in road dust from an industrial city in semi-humid area of Northwest China. Journal of Radioanalytical and Nuclear Chemistry, 303, 637, 2015.

5. ARYAL R., BEECHAM S., SARKAR B., CHONG M.N., KINSELA A., KANDASAMY J., VIGNESWARAN S. Readily Wash-Off road dust and associated heavy metals on motorways. Water Air Soil Pollution, 228 (1), 2017.

6. SVAJLENKA J., KOZLOVSKÁ M., POŠIVÁKOVÁ, T., ČONKOVÁ, E. Indoor analysis of environment in building. Chemical letters, 11 (6), 398, 2017.

7. RICE M.B., LJUNGMAN P.L., WILKER E.H., DORANS K.S., GOLD D.R., SCHWARTZ J., KOUTRAKIS P., WASHKO G.R., O'CONNOR G.T., MITTLEMAN M.A. Long-term exposure to traffic emissions and fine particulate matter and lung function decline in the Framingham hearth study. American Journal of Respiratory and Critical Care Medicine, 191 (6), A3201, 2015

8. BRADL H., KIM C., KRAMAR U., STUBEN D. Interactions on Heavy Metals. In Heavy metals in the environment, $3^{\text {rd }}$ ed.; Bradl, H.B., Eds., Academic Press: Amsterdam, 98, 2005.

9. GUPTA G.P., KUMAR B., SIGH S., KULSHRESTHA U.CH. Deposition and Impact of Urban Atmospheric Dust on Two Medicinal Plants during different seasons in NCD Delhi. Aerosol Air Quality Research, 16, 2920, 2016.

10. TRUJILO-GONZÁLEZ J.M.T., TORRES-MORA M.A., KEESSTRA S., BREVIK E.C., JIMÉNEZ-BALLESTRA R. Heavy metal accumulation related to population density in road dust samples taken from urban sites under different land uses. Atmospheric Environment, 553, 636, 2016.

11. GOVIND P., MADHURI S. Heavy metals causing toxicity in animals and fishes. Research Journal of Animal, Veterinary and Fishery Sciences, 2 (2), 17, 2014.

12. XIAO R., WANG S., LI R., WANG J.J., ZHANG Z. Soil heavy metal contamination and health risks associated with artisanal gold mining in Tongguan, Shaanxi, China. Ecotoxicology and Environmental Safety, 141, 17, 2017.

13. DAI Y., HOU X., ZHANG Y., YANG T., LI M., XU X. Elevated lead levels and changes in blood morphology and erythrocyte CR1 in preschool children from an e-waste area. Science of Total Environment, 592, 51, 2017.

14. MEGIDO L., SUÁREZ-PENA B., NEGRAL L., CASTRILLÓN L., FERNÁNDEZ-NAVA Y. Suburban air quality: Human health hazard assessment of potentially toxic elements in PM10. Chemosphere, 177, 284-291, 2017.

15. GODISH T, DAVIS, W.T., FU J.S. Air Quality, 4th ed.; A CRC Press Company, Taylor and Francis Group, New York, 122, 2015.

16. LIU Q., LIU Y., YIN J., ZHANG M., ZHANG T. Chemical characteristics and source apportionment of PM10 during Asian dust storm and non-dust storm days in Beijing. Atmospheric Environment, 91, 85, 2014.

17. JANTA R., CHANTARA S., INTA A., KAWASHIMA M., STAKE K. Levels of road traffic heavy metals in tree 
bark layers of Cassia fistula Tree. International Journal of Environmental Science and Development, 7, 385, 2016.

18. DEMKOVÁ L., BARANOVÁ B., OBOŇA J., ÁRVAY J., LOŠÁK T. Assessment of air pollution by toxic elements on petrol stations using moss and lichen bag technique. Plant Soil and Environment, 63, 355, 2017a.

19. VAN DER WAT, L, FORBES P.B.C. Lichens as biomonitors for organic air pollutants. Trends in Analytical Chemistry, 64, 165, 2015.

20. PAOLI L., MUNZI S., GUTTOVÁ A., SENKO D., SARDELLA G., LOPPI S. Lichens as suitable indicators of the biological effects of atmospheric pollutants around a municipal solid waste incinerator (S Italy). Ecological Indicators, 52, 362, 2015.

21. SHUKLA V., URPETI D.K., BAJPAI R. Lichens to biomonitor the environment. Springer New Delhi Heidelberg: New York, Dordrecht London, 2014.

22. DEMKOVÁ L., BOBULSKÁ L., ÁRVAY J., JEZNÝ T., DUCSAY L. Biomonitoring of heavy metals contamination by mosses and lichens around Slovinky tailing pond (Slovakia). Environmental Science and Health, Part A: Toxic/Hazardous Substances and Environmental Engineering, 52 (1), 30, 2017b.

23. WATMOUGH S.A., RABINOWITZ T., BAKER S. The impact of pollutants from a major northern highway on an adjacent hardwood forest. Science of Total Environment, 579, 409, 2017.

24. GAUSLAA Y., YEMETS O.A., ASPLUND J., SOLHAUG K.A. Carbon based secondary compounds do not provide protection against heavy metal road pollutants in epiphytic macrolichens. Science of Total Environment, 541, 795, 2016.

25. GODMAN T.G., ROBERTS T.M. Plant and soils as indicators of metals in the air. Nature, 231, 287, 1971.

26. BOCHNÍČEK O., BORSÁNYI P., ČEPČEKOVÁ E., FAŠKO P. Climate Atlas of Slovakia. Slovak hydrometeorological institute: Bratislava, 2015 [In Slovak].

27. CARBALlEIRA A., CARRAL E., PUENTE X., VILLARES R. Regional-scale monitoring of coastal contamination. Nutrients and heavy metals in estuarine sediments and organisms on the coast of Galicia (northwest Spain). International Journal of Environmental Pollution, 13, 534, 2000.

28. SALO H., BUCKO M.A., VAAHTOVUO E., LIMO J., MAKINEN J, PERSONENL J. Biomonitoring of air pollution in SW Finland by magnetic and chemical measurments of moss bags and lichens. Journal of Geochemical Exploration, 115, 69, 2012.

29. OSM (OpenStreetMap) (2016) Available at: https://www. openstreetmap.org/\#map=4/50.18/-1.41. (accessed 10 November 2017)

30. BOAMPONSEM L.K., ADAM J.I., DAMPARE S.B., NYARKO B.J.B., ESSUMANG D.K. Assessment of atmospheric heavy meal deposition in the Tarkwa gold mining area of Ghana using epiphytic lichens. Nuclear Instruments and Methods in Physics Research, 268, 1492, 2010.

31. ZIGMOND A.R., URÁK I. Assessment of heavy metal content of lichen and soil collected from Hasmas Mountains (Romania). Biharean Biologist, 5, 69, 2011.

32. KLIMEK B., TARASEK A., HAJDUK J. Trace Element Concentrations in Lichens Collected in the Beskidy Mountains, the Outer Western Carpathians. Bulletin of Environmental Contamination and Toxicology, 94, 532, 2015.
33. MARKERT B. Presence and significance of naturally occurring chemical elements of the periodic system in the plant organism and consequences for future investigations on inorganic environmental chemistry in ecosystems. Vegetatio, 103, 1, 1992.

34. MARKERT B. Plants as biomonitors - Potential Advantages and problems. In Biogeochemistry of Trace Elements, Adriano D.C., Chen Z.S., Yang S.S., Eds., Science and Technology Letters: Northwood, 601, 1994.

35. MANNO E., VARRICA D., DONGARRA G. Metal distribution in road dust samples collected in an urban area close to a petrochemical plant at Gela, Sicily. Atmos Environment, 40, 5929, 2006.

36. PETIT D., VÉRON A., FLAMENT P., DEBOUDT K., POIRIER A. Review of pollutant lead decline in urban air and human blood: A case study from northwestern Europe. Comptes Rendus Geoscience, 347 (5-6), 247, 2015.

37. PULLES T., VAN DER GON H.D., APPELMAN W., VERHEUL M. Emission factors for heavy metals from diesel and petrol used in European vehicles. Atmos Environ 61, 641, 2012.

38. LI X.D., POON C., LIU P.S. Heavy metal contamination of urban soils and street dusts in Hong Kong. Applied Geochemistry, 16, 1361, 2001.

39. CHARLESWORTH S., EVERETT M., MCCARTHY R., ORDÓÑEZ A., DE MIGUEL E. A comparative study of heavy metal concentration and distribution in deposited street dusts in a large and a small urban area: Birmingham and Coventry, West Midlands, UK. Environment International, 29, 563, 2003.

40. ZHAO N., LU X., CHAO S., XU X. Multivariate statistical analysis of heavy metals in less than $100 \mu \mathrm{m}$ particles of street dust from Yining, China. Environmental Earth Sciences, 73 (5), 2319, 2015.

41. STERNBECK J., SJÖDIN A., ANDRÉASSON K. Metal emissions from road traffic and the influence of resuspension - results from two tunnel studies. Atmospheric Environment, 36, 4735, 2002.

42. KABATA-PENDIAS A. Trace elements in soil and plants. CRC Press: Taylor and Francis Group, 2011.

43. WANG Y., YANG L., KONGL., LIU E., WANG L, ZHU J. Spatial distribution, ecological risk assessment and source identification for heavy metals in surface sediments from Dongping Lake, Shandong, East China. Catena, 125, 200, 2015.

44. SAXENA S., UPRETI D.K., SHARMA N. Heavy metal accumulation in lichens growing in north side of Lucknow city. Journal of Environmental Biology, 28 (1), 45, 2007.

45. SCERBO R., RISTORI T., POSSENTI L., LAMPUGNANI L., BARALE R., BARGHIGIANI C. Lichen (Xanthoria parientina) biomonitoring of trace element contamination and air quality assessment in Pisa Province (Tuscany, Italy). Science of Total Environment, 286, 27, 2002.

46. SHARMA S.K., MANDAL T.K., SAXENA M., RASHMI R.,SHARMA A., GAUTAM R. Source of apportionment of PM10 by using positive matrix factorization at an urban site of Delhi, India. Urban Climate, 10, 656, 2014.

47. GERDOL R., MARCHESINI R., IACUMIN P., BRANCALEONI L. Monitoring temporal trends of air pollution in an urban area using mosses and lichens as biomonitors. Chemosphere, 108, 388, 2014.

48. YENISOY KARAKAS S., TUNCEL S.G. Geographic patterns of elemetal deposition in the Aegean region of Turkey indicated by the lichen, Xanthoria parietina (L.) Th, Fr. Science of Total Environment, 329, 43, 2004. 